\title{
A telenovela como narrativa identitária do país no cenário complexo da contemporaneidade
}

pg $88-100$

\author{
Rondinele Aparecido Ribeiro ${ }^{1}$ \\ Francisco Cláudio Alves Marques²
}

\section{Resumo:}

A telenovela é um gênero de ficção audiovisual de grande importância para a história da televisão brasileira. Inicialmente concebida como um produto menor na grade de programação, ao longo de sua trajetória, passou a incorporar elementos tecnológicos, adquiriu uma linguagem peculiar e incorporou elementos do realismo. Enquanto objeto privilegiado de construção de uma narrativa sobre o país, a telenovela, na atualidade, tem se constituído por tramas cada vez mais naturalistas ao explorar temáticas ligadas ao cotidiano do brasileiro, mostrando seu grande potencial comunicativo, como defende Lopes (2014). A partir dessas considerações, este trabalho intenciona elucidar a trajetória da telenovela no Brasil bem como mostrar como esse gênero comunicativo incorporou temáticas sociais em seu enredo de modo a se constituir como uma verdadeira narrativa identitária acerca do país no cenário complexo da contemporaneidade marcado pela fragmentação do indivíduo e pela redefinição de identidades.

Palavras-chave: Telenovela. Ficção. Recurso Comunicativo. Identidade.

\section{THE TELENOVELA AS IDENTITY NARRATIVE OF THE COUNTRY IN THE COMPLEX SCENARIO OF CONTEMPORARY}

\begin{abstract}
The telenovela is a genre of audiovisual fiction of great importance for the history of Brazilian television. Initially conceived as a minor product in the programming grid, throughout its trajectory, it began to incorporate technological elements, acquired a peculiar language and incorporated elements of realism. As a privileged object of construction of a narrative about the country, the telenovela, today, has been constituted by increasingly naturalistic plots when exploring themes linked to Brazilian daily life, showing its great communicative potential, as Lopes (2014) argues. Based on these considerations, this work intends to elucidate the telenovela trajectory in Brazil as well as to show how this communicative genre incorporated social themes in its plot so as to constitute as a true identity narrative about the country in the complex scenario of contemporaneity marked by the fragmentation of the And by the redefinition of identities.
\end{abstract}

Keywords: Telenovela. Fiction. Communicative Resource. Identity.

\section{Introdução}

$\mathrm{O}$ ato de narrar é uma necessidade essencialmente humana. Enquanto meio de expressão oral ou escrita, apresenta uma variedade de formas e está presente desde os primórdios em todas as sociedades

1 Mestrando no Programa de Pós-graduação em Letras da UNESP-ASSIS ( linha Literatura e Estudos Culturais).

2 Mestrando da UNESP/Assis. 
constituindo-se numa forma de intercambiar experiências e entretenimento. Há inúmeras definições para o ato narrativo, também é verdade que muitos estudiosos se debruçaram e se debruçam na tarefa de definir um instinto tão primitivo quanto esse.

A grande verdade é que as narrativas se consubstanciam como produtos culturais, os quais são organizados e maneira sistemática por meio de signos, que exigem um mínimo grau de manipulação da linguagem. Dessa forma, é lícito concluir que "a origem da história em capítulos confunde-se com a origem da própria história do homem" (ALENCAR 2002, p.41). Assim, uma das grandes maneiras de se conhecer profundamente uma sociedade é conhecer suas histórias repletas de conflitos, costumes e medos. Isso ocorre, porque o grande fio condutor das histórias é a experiência e valores de uma sociedade. Como se sabe, as histórias compõem o grupo de ações destinadas a preservar e a fazer evoluir a espécie humana. Por meio delas, uma tribo ou um povo pode garantir a sobrevivência de suas crias e manter o conhecimento relativo à sua continuidade (SADEK, 2008). Nessa mesma esteira, Sadek (2008, p.18) acrescenta que o prazer de estar em conjunto, de desfrutar a companhia dos demais, de passar momentos comungando os mesmos sentimentos e os mesmos rituais também torna as histórias momentos necessários às tribos humanas e ansiados por elas. $\mathrm{Na}$ sequência, o estudioso conclui: "Benéficas, a serviço de forças mal-intencionadas ou ambas, as histórias têm sido contadas desde que o homem articulou signos" (SADEK, 2008, p.19).

Ao longo dos séculos, o ato de narrar sofreu profundas alterações quanto à sua forma e quanto ao seu suporte de divulgação. Assim, da primeira narrativa oral, passando pelo suporte escrito até se constituir numa legítima simbiose de códigos, a telenovela emergiu na sociedade audiovisual como gênero por excelência. Inspirada nas narrativas folhetinescas, o gênero herdou as principais características de sua matriz literária, tais como a representação de enredos que promoviam amplamente a identificação do receptor com a obra e o gancho como forma de forjar o receptor a continuar acompanhando a produção.

Ao longo de mais de 60 anos de exibição no país, a telenovela tornou-se o gênero televisivo de maior sucesso, que responde na contemporaneidade pelo velho hábito de contar histórias, cumprindo um papel social, político e pedagógico à medida em que se liga diretamente à representação da realidade, promovendo amplamente a identificação com o receptor e esclarecendo sobre algumas condutas.

Muito longe de esgotar o tão vasto campo de confluências entre a narrativa literária e a narrativa seriada audiovisual, o presente artigo se propõe a tecer considerações acerca da narratividade e de sua importância para a humanidade. Para tanto, emprega tessituras sobre as especificidades do ato narrativo e de suas alterações ao longo dos séculos sofridas pela alteração do suporte até a atualidade marcada pela narrativa de ficção seriada audiovisual como grande fonte promotora do acesso ao entretenimento. Avança também na hipótese do gênero se constituir como uma narrativa identitária acerca do país.

\section{A literatura parcelada nos jornais}

O jornal teve grande importância para a modernidade. Mais que levar informações, tal veículo de comunicação foi responsável pela propagação de um gênero literário de extrema importância para a literatura: o folhetim. A gestação desse gênero popularesco se deu na França e ocorreu no momento em que Emile Girardin, editor do Jornal La Presse, desejou revigorar o jornal, tornando-o mais popular. Assim, a ascensão dessa modalidade de narrativa está intrinsicamente ligada ao surgimento da literatura de massa. Para entender esse fenômeno de vendas, é necessário recorrer 
ao contexto no qual sua gênese está atrelada: um contexto repleto de mudanças na sociedade europeia cujo grande agente é a Revolução Industrial, que propiciou o surgimento de uma sociedade aberta, móvel com enorme necessidade de consumir.

Nesse sentido, ao incluir o folhetim como estratégia de venda nos jornais, atendeu-se a um apelo capitalista, uma vez que a publicação de narrativas literárias no jornal significava a ampliação no número de leitores e, consequentemente, alavancou o número de vendas, como foi o caso do Jornal La Presse. O aumento vertiginoso do número de assinaturas possibilitou ao jornal diminuir o preço, tornando-o mais acessível ao público leitor, o que contribuiu para legar entretenimento e ficção às massas.

Perscrutar a configuração desse gênero é se debruçar num período conturbado, uma vez que a França experimentava uma situação marcada pela censura política. Nesse contexto, ocorre a ampliação conferida ao folhetim nos jornais, surgindo um espaço profícuo para publicação de histórias parceladas. Vale acrescentar que tal espaço já existia, sendo que, antes de Girardin, o termo folhetim era empregado para designar o suplemento destinado à crítica literária e a outros temas. A partir da atitude de renovação implementada por Emile Girardin, o gênero folhetim revigorou-se. Assim, conforme esclarece Alencar (2002, p.42), tais narrativas "seriam histórias de amor e aventura no chamado estilo folhetim miscelânea, nas escola romântica e no melodrama do teatro popular".

Girardin e seu ex-sócio, Armand Dutacq logo perceberam enormes vantagens financeiras que teriam com a publicação de folhetins em seus jornais. Dessa forma, La Presse e o Le Siécle foram os grandes precursores no que se refere à publicação desse gênero. A estreia se deu em 05 de agosto de 1836, quando o jornal de Girardin iniciou a publicação de Lazarillo de Tormes. Todavia, tal publicação ainda não contava com as características folhetinescas, sobretudo, pelo fato de não ter sido concebida com o intuito de ser publicada diariamente em formatos parcelados nos rodapés de jornais. O sucesso dessa modalidade literária foi tão grande, que no ano de 1840, o folhetim já estava estabelecido como importante gênero literário, tanto é que grandes escritores franceses eram disputados pelos jornais para produzirem romances-folhetins. Esse fenômeno cultural alastrou-se por toda a Europa, tanto é que em alguns jornais mais populares, tiveram a publicação de seis folhetins ao mesmo tempo.

Para garantir o sucesso de público, os folhetins passaram a empregar em sua estrutura basicamente dois recursos literários. O primeiro recurso é o suspense, que tem como marca principal o emprego do gancho, o que garantia que o leitor mantivesse o interesse na continuação da história que seria publicada no dia seguinte. Já o segundo recurso, é a redundância com o intuito e recapitular a trama, o que servia como forma de esclarecimento para aquele leitor que estava acompanhando a história a partir daquele momento.

Sobre o emprego do gancho, valem as explicações de Costa:

O gancho - essa ferramenta com a qual o
narrador seciona sua história em pedaços,
mantendo o interesse e avivando a curiosidade
de seu interlocutor - é uma intrincada gramática
que exige todo um "amarramento" próprio
da trama. Os ganchos sintetizam os capítulos
diários de uma narrativa seriada, demonstrando
que as intrigas foram urdidas exatamente para
terminarem nesse hiato preciso e calculado -
é como se o narrador começasse a escrever
o capítulo, pensando já em como encerrá-
lo. Podemos dizer que quem escreve tanto
conta como sugere o que não conta, quando
silencia, corta ou interrompe. Há um enredo
que se apresenta no texto e outro que se
esconde na imaginação do público, proposto
pelo narrador. O gancho acentua os silêncios,
as propostas, as ambiguidades, as sugestões,
estimula os desejos, as expectativas, os sonhos
(COSTA, 2001, p.04).

Analisado sob esse viés, percebe-se que o traçado histórico do folhetim é inerente à própria 
história do século XIX do ponto de vista social e estrutural. A esse respeito Alencar (2002) comenta que mesmo tendo surgido novas formas de comunicação e de entretenimento - grandes formas de promoção artística, a estrutura folhetinesca permaneceu.

Arnt (2004) sustenta a tese de que irá ocorrer no século XIX uma profunda associação entre literatura e jornalismo. "No século XIX, literatura e jornalismo vão ser indissociáveis. Os maiores escritores da literatura universal passaram pela imprensa, não só como jornalistas, mas como cronistas, escritores de folhetins e romancistas" (ARNT, 2004, p.47). A essa fase, a estudiosa denomina de jornalismo literário e vai mais além ao delimitar que esse período se estende de 1830 ao final do século. Analisado sob esse viés, percebe-se que o traçado histórico do folhetim é inerente à própria história do século XIX do ponto de vista social e estrutural.

Cumpre o dever de lembrar que no Brasil, a publicação dos folhetins está atrelada à história de leitura do país, já que os livros constituíam um objeto cultural quase inacessível à maioria da população devido à pouca atividade de imprensa. Assim, o jornal irá cumprir o papel de atividade cultural, sendo um espaço para a publicação de folhetins, romances e contos. Aqui, o primeiro romance brasileiro só foi publicado em 1843 por Teixeira e Souza, todavia, o primeiro romancefolhetim publicado em solo brasileiro foi O Capitão Paulo, em 1838, do escritor Alexandre Dumas, que fora publicado no Jornal do Commercio.

Sadek (2008) assevera que o Brasil se alfabetizou enquanto lia folhetins. Isso posto, porque esse gênero passa a fazer parte do cotidiano brasileiro no momento em que o país estava se formando enquanto nação. Trata-se de um momento de formação da leitura em uma sociedade marcada por um grande número de analfabetos.
Como a atividade de reprodução tipográfica só foi permitida a partir da vinda da família real para o Brasil em 1808 associada ao projeto de exploração da metrópole que proibiu na colônia o desenvolvimento de uma cultura letrada em face de uma possível despertar de consciência crítica, o que levaria a possível confronto com os ideias de exploração da metrópole, não se desenvolveu na colônia qualquer atividade que pudesse propagar uma cultura letrada. Era verdade que circulava na colônia obras, mesmo que proibidas pela metrópole, mas não era o suficiente para desenvolver um público leitor. Vale acrescentar também que na época não se tinha universidades, o que fazia o país mergulhar ainda mais em um atraso, se comparado ao restante dos países.

Sobre a situação apresentada, valem as tessituras de Sadek:

O Brasil que recebeu a primeira prensa somente
em 1808 , com a vinda de D. João VI, tinha
naquele momento menos de $3 \%$ da população
alfabetizada. Lentamente, mais brasileiros
foram aprendendo a ler, e, ao, mesmo
tempo, os jornais foram aparecendo, com
folhetins incluídos. A difusão dos folhetins e
a alfabetização de maior parcela da população
brasileira são contemporâneas, e, ainda que
sem comprovação documental, é razoável
pensar que o Brasil se alfabetizou enquanto lia
folhetins. O encanto pelas histórias parceladas
veio das elites cultas (que liam jornais) e
contaminou outras porções da população que
se iniciavam nas letras (SADEK, 2008, p. 31).

Boa parte dos grandes escritores brasileiros do século XIX como postula Arnt (2004), encontraram no jornal uma forma de publicar suas obras. Assim, escritores que perfazem um cânone militaram na imprensa, o que mostra o quanto no Brasil será importante o jornalismo literário para a formação e promoção da leitura. Só para citar, podemos incluir no rol daqueles que passaram pelo jornal Joaquim Manoel de Macedo, Raul Pompeia, Aloísio de Azevedo, Euclides da Cunha, José de Alencar, Machado de Assis e Manuel Antônio de Almeida. 


\section{A telenovela: um folhetim eletrônico}

A telenovela é um gênero de ficção seriada consideradaherdeirodo formatodogênero folhetim, bem como aspecto estrutural melodramático. Sua origem está atrelada a Cuba, que exportou o gênero para vários países latino-americanos, tais como México e Argentina até a chegada no Brasil. Escritas em capítulos, as telenovelas constituem-se como o principal produto da ficção televisiva, respondendo pela promoção do acesso à ficção, pelo sucesso comercial das emissoras (principalmente da Rede Globo), pela (s) (re)configuração(ões) identitária(s) do país. Tendo sua origem a partir do folhetim, do melodrama e das soap operas, a telenovela passou a ser objeto acadêmico de estudos, o que muito serviu para abandonar o ponto de vista majoritário que grassou no meio de que se tratava de um produto alienante. Assim, esse gênero passou a se constituir em uma narrativa brasileira por excelência capaz de documentar a realidade justamente por ter evoluído conjuntamente com o seu suporte (nesse sentido, sua trajetória se confunde com a da televisão) e com o próprio país, o qual passou por inúmeras transformações desde os anos 1950.

Esse gênero caracterizado como a expressão máxima televisiva daindústria cultural, notoriamente alterou o seu formato desde a primeira exibição no Brasil em 1951. De um produto menor na grade de programação televisiva e de conteúdo evasivo, a telenovela, a partir da década de 1960, passou a tratar de temáticas inerentes ao cotidiano do país, o que muito serviu para promover uma verdadeira identificação do público com o enredo cada vez mais próximo da realidade experimentada. Podese dizer, então, que enquanto suporte narrativo por excelência, a televisão e seu gênero telenovela diluiu as fronteiras entre a realidade e o ficcional.

Renata Pallottini define essa produção:
A telenovela de modelo brasileiro, talvez latinoamericano, é uma história contada por meio de imagens televisivas, com diálogo e ação, uma trama principal e muitas subtramas que se desenvolvem, se complicam e se resolvem no decurso da apresentação. Naturalmente, a trama planejada como a principal é a que leva o enredo básico, a fábula mais importante, do começo ao fim da ação, e a que justifica todo o projeto, dando-lhe unidade (PALLOTTINI, 2012, p. 48)

Wanderley Postigo defende a tese de que a telenovela é um gênero híbrido devido a mescla que realiza em diversas matrizes. "Assim, a telenovela une recursos do teatro, do cinema e do rádio bem como, por meio dos folhetins e da forma de se fazer um roteiro, da literatura" (POSTIGO, 2008, p. 316). Notoriamente, ao se analisar sua origen, pode se dizer que tal produto sintetiza as características essenciais da indústria cultural: a diluição das fronteiras entre o erudito e o popular para criação de um novo gênero. Assim, sobre a constituição do gênero telenovela, faz-se de extrema importância esclarecer que tal produção televisiva tem uma história que se confunde com a introdução de seu suporte no Brasil, já que estão presentes desde a implantação da televisão no país.

É bom lembrar que, de início, esse gênero era considerado produto menos nobre, se comparado ao teleteatro, que contava com grande número de atores do teatro e empregava roteiros adaptados das obras literárias. Enquanto aspectos técnicos, é importante frisar que, nos seus primórdios, a teledramaturgia não contava com a linguagem própria tampouco contava com o tão propalado nível de acabamento que tais produções alcançaram, fazendo com que o Brasil ficasse conhecido como "o país das telenovelas".

Imperava nas produções iniciais, de acordo com Sadek (2008, p.12) um caráter improvisado. “O começo da TV no Brasil foi improvisado. Ela foi trazida praticamente num rompante na década de 1950, e, como não havia gente especializada nesse trabalho, os técnicos do rádio foram requisitados 
para fazer os primeiros programas da TV”. Já que no tange às temáticas, pode-se falar que, nessa fase inicial, grande parte dos roteiros eram adaptações de obras literárias. Tal estratégia era empregada para legitimar um gênero incipiente, que não contava ainda com um formato profissional.

Vale ressaltar, contudo, que mesmo o gênero estando calcado numa estrutura narrativa similar ao do folhetim, a telenovela passou por várias transformações, sobretudo, porque incorporou novas tecnologias e consolidou-se como gênero de forte aceitação popular por veicular temáticas cada vez mais envolventes, as quais dialogam com a realidade dos receptores, além de procurar cada vez mais interação com o público-alvo. Suas características melodramáticas foram abandonadas em parte por uma linguagem própria, o que propiciou contextualizar e representar os confrontos e problemas da sociedade.

Vale ressaltar que as características ora descritas começaram a ser percebidas a partir dos anos 1960, tendo o auge nos anos 1970 em plena ditadura. Alguns estudiosos apontam que essa década deve ser encarada como o período de grande nível apurado das produções. A grande verdade é que a novela passou a se constituir num precioso instrumento de integração nacional, representando papeis sociais, ligando a conquistas políticas, representando comportamentos, esclarecendo determinadas condutas, refletindo determinadas lutas de classes e de gêneros, criando hábitos de consumo, produzindo padrões e normas. Enfim, foi alçada ao posto de grande instrumento de integração nacional ou, como assevera, Lopes (2009), numa narrativa sobre a nação e uma forma de participar dessa nação imaginada.

De fato, observa-se que ocorreu a aproximação da realidade muito próxima com a ficção. Desse resultado, a telenovela conseguiu penetrar ativamente na casa dos brasileiros, promovendo uma maior identificação, o que levou a uma projeção muito maior da obra, podendose falar que a teleficção passou a cumprir uma função social à medida que estabelece referência a um universo que é exterior à narrativa, assumindo um papel explícito de intervenção em histórias, funcionando como grandes prestadoras de serviços à sociedade, o que corresponde à função comunicativa que Lopes $(2009,2014)$ atribui para esse gênero.

\section{Uma sistematização para o estudo da telenovela}

No Brasil, as telenovelas correspondem a uma forma de narrativização da sociedade. Constituindo-se como carro chefe da teleficção, esse gênero retrata aspectos ligados à intimidade dos brasileiros e dá visibilidade a temas considerados polêmicos. Enquanto produto de mídia, a telenovela é um produto de maior aceitação na sociedade e o que mais capacidade tem de penetrar no cotidiano da sociedade devido ao seu caráter de conseguir constituir-se num verdadeiro gênero de visibilidade social e alimentar um repertório compartilhado de conteúdos. "No Brasil, frequentemente mais da metade dos aparelhos de TV ligados sintonizam mesma telenovela, que, em contato diário com os espectadores, lança modas, induz comportamentos, opina acerca de polêmicas, presta serviços e participa do cotidiano do país" (SADEK, 2008, p.11). Essa forma de narrativa, audiovisual, não resta dúvidas, é um objeto cultural brasileiro: "é possível afirmar que a telenovela conquistou reconhecimento público como produto estético e cultural, convertendo-se em figura central da indústria televisiva e da cultura do País" (LOPES; MUNGIOLI, 2013, p.10).

Estabelecendo-se um cânone para essa modalidade de narrativa no país, é oportuno seguir a divisão proposta por Maria Immacolata Vassallo de Lopes, que dividiu a história do gênero no 
país em 3 fases: sentimental (1951-1967), realista (1968 - 1990) e naturalista (a partir dos anos 1990). De acordo com a divisão proposta pela autora, a primeira fase corresponde aos primeiros anos de exibição do gênero, fase classificada pela estudiosa como sentimental devido aos aspectos extremamente melodramáticos presentes nas primeiras produções teleficcionais. Nessa fase incipiente, sobressaiu uma visão bastante maniqueísta a que as personagens eram submetidas, chegando, muitas vezes, à inverossimilhança. Outra característica recorrente nas produções desse período está associada ao caráter alienante e evasivo, uma vez que a realidade nacional não figurava no enredo das primeiras telenovelas, os quais eram permeados por ambientações bastante distantes $\mathrm{e}$ artificiais, fazendo com que a telenovela fosse vista como um gênero desqualificado e alienante.

Pode-se muito bem definir essa fase incipiente como uma fase experimental. Basta lembrar que o gênero telenovela não era a principal produto das emissoras, sua exibição não era diária e o formato era “ao vivo”. Apenas nos anos 1960 é que se teve a incorporação de aparato tecnológico responsável por conferir ao gênero a captação das imagens e a edição para sua veiculação nacional. Para Sadek (2008, p.35), a partir da adoção do videoteipe nos anos 1960, ocorreu a operacionalização dessa narrativa $\mathrm{e}$ as telenovelas passaram a ser mais viáveis. "O VT é o divisor de águas na história da televisão em todo o mundo. Deu-lhe sentido de obra duradoura, como o cinema" (TÁVOLA, 1996, p.75).

Em 1963, a TV Excelsior importou da Argentina o modelo de telenovela que impera até hoje o Brasil: o formato diário, sendo inaugurado pela telenovela 2-5499 Ocupado, do argentino Tito di Miglio. A trama, originalmente denominou-se “0597 Dá ocupado”. Constitui-se como sendo a primeira telenovela exibida diariamente no país. “Telencenada” pela TV Excelsior, em São Paulo,

no horário das 19 horas, foi exibida de julho a setembro de 1963. " A ideia de transmissão diária dos capítulos nasceu de uma viagem de Edson Leite, superintendente da TV Excelsior, à Argentina, onde viu novelas exibidas diariamente, sempre no mesmo horário. Ao voltar, comprou os direitos da novela [...] (TÁVOLA, 1996, p.86). Dessa forma, como pontua Alencar (2002, p.20), "mais de uma década depois, as histórias, antes contadas duas ou três vezes por semana, passaram a ser diárias". Conforme asserções de Távola (1996), a referida novela não logrou tanto sucesso. Assim, seu registro é apenas necessário pelo alto valor histórico. Para Hamburger (2005), o formato de exibição diário da telenovela foi fundamental para se conquistar a atração do público e fisgar audiências. Assim, essa estratégia inicial empregada nos anos 60 irá se consolidar na década posterior.

A estudiosa Alina Aires explica que a importação do modelo diário mostrou o caráter industrial que o gênero acabou experimentando:

O advento da telenovela diária está diretamente relacionado com esse esquema industrial e alcançam sucesso rápido. Dentre novelas importadas e radionovelas brasileiras adaptadas do rádio, o período é marcadamente caracterizado pela presença do melodrama. Imperava o estilo fantasioso de Glória Magadan, autora e diretora das maiores telenovelas veiculadas pela Rede Globo no período, como "O Sheik de Agadir" e "Sua Vida me pertence” (AIRES, 2014, p.09)

Lopes(2009;2014)incluiunosegundoperíodo, compreendido entre 1968 a 1990, as produções que passaram a se constituir numa intensa veiculação de debates acerca da modernização brasileira. Pode-se dizer que as telenovelas produzidas nessa fase puderam captar as alterações experimentadas pelo Brasil no cenário, político, econômico e social. Do ponto de vista político, as produções foram responsáveis pela diluição da extensa carga melodramática que imperava no gênero, cabendo a Beto Rockfeller (exibida entre 1968 e 1969) mudar 
o paradigma evasivo e melodramático que operava nas produções teleficcionais.

Considerada revolucionária por empregar como protagonista um anti-herói, um verdadeiro enganador que vendia sapatos em um bairro popular e queria ingressar no mundo dos ricos, Beto Rockfeller representa um verdadeiro "divisor de águas" na história da teledramaturgia nacional. Para Sadek (2008), essa telenovela é a primeira considerada moderna, com temática bastante atual. Ela foi responsável por atrair o público masculino, até então, ausente das telenovelas, já que elas eram, em sua essência, melodramáticas. Em sua tessitura, Beto Rockefeller inovou empregando diálogos marcados pela coloquialidade e pelo emprego de gírias. "A encenação era naturalista. Espectadores ricos e pobres ficaram encantados com as manobras de Beto para participar de um mundo que não era o seu” (SADEK, 2008, p.37). "Após grande sucesso, esta telenovela abriu caminho para a renovação e modernização do formato, dialogando com o projeto de urbanização e modernização do Brasil, e promovendo uma revolução estética definitiva na linguagem das telenovelas [...]” (AIRES, 2014 p.02).

Conforme salienta Hamburger (2005), a liberalização dos costumes pela qual o Brasil passou nesse amplo processo de modernização foi responsável pelo oferecimento de material necessário para que as tramas desenvolvessem seu enredo. A estudiosa aponta ainda que as produções dessa fase seguiram uma concepção quase didática, sobretudo, por terem sido estruturadas em função dos aspectos sociais, que impulsionaram a transformação do país. "A oposição entre o Brasil tradicional e o Brasil moderno que mobilizou a militância política e cultural brasileira nas décadas de 150-60 está difundida nas novelas do período 1970-90” (HAMBURGER, 2005, p.100). Nessa fase, pode-se dizer também que ocorreu uma grande diversificação técnica empregada nas produções, além da diluição das fronteiras entre o real e o ficcional. Ao alinhar uma estrutura teledramática com a contemporaneidade, a telenovela propiciou uma verdadeira interação com os telespectadores, promovendo a captação de referências do país que abandonava sua condição agrária para adentrar no cenário globalizado.

Ao se posicionar sobre a importância dessa telenovela para a teledramaturgia nacional, Lopes assevera:

\begin{abstract}
Esse paradigma trouxe a trama para o universo contemporâneo das grandes cidades brasileiras. $\mathrm{O}$ uso de gravações externas introduziu a linguagem coloquial, o humor inteligente, uma certa ambiguidade dos personagens e, principalmente, um repertório de referências compartilhado pelos brasileiros. Sintonizou as ansiedades liberalizantes de um público jovem, tanto masculino como feminino, recémchegado à metrópole, em busca de instrução e integração nos polos de modernização (LOPES, 2009, p.25)
\end{abstract}

Por fim, a última fase compreendida pela estudiosa como fase naturalista, estrutura-se a partir dos anos 1990 e conta com a forte presença de elementos realistas, os quais caracterizaram a fase anterior com a diferença de que na atual fase a verossimilhança é atingida quando se emprega temáticas cada vez mais sociais mantendo um diálogo constante com a realidade. Para a autora, as tramas desse período apresentam um forte discurso que dialoga diretamente com as situações experimentadas pela sociedade em seu dia a dia. Como uma característica dessa fase, Lopes defende que a telenovela deve ser vista como um recurso comunicativo, ou seja, “[...] identificá-la como narrativa na qual se conjugam ações pedagógicas tanto implícitas quanto deliberadas que passam a institucionalizar-se em políticas de comunicação e cultura no país" (LOPES, 2009, p.32).

A partir da inserção desse viés mais naturalista nas ficções televisivas, pode-se entender que esse vasto conjunto de referências narrativas passam a ser um nutriente na memória do receptor. Notoriamente, a telenovela é alçada ao status de 
objeto artístico e estético notabilizando-se como fator de humanização, posto que pode educar e edificar. Enquanto objeto estético, propicia ao leitor entrar em contato com um mundo que não é o seu, servindo como um agente de ampliação dos horizontes de expectativas. Nesse sentido, estimula o senso crítico e o senso de cidadania, servindo como amplo espaço de reflexão por representar os conflitos humanos e torná-los próximos da sociedade. "Acreditamos que abordar a telenovela como recurso comunicativo é identificá-la como narrativa na qual dispositivos discursivos naturalistas ou documentarizantes passam a ser deliberadamente explicitados e combinados com diversificações da matriz melodramática da telenovela" (LOPES, 2014, p.05).

A narrativa televisiva é capaz de representar temáticas cada vez mais cotidianas do universo brasileiro, que muito serve como um estímulo ao senso crítico e propicia um amplo espaço de reflexão, o que Lopes $(2009$; 2014) define como potencialidade de a telenovela constituir-se como uma agenda setting, justamente por servir como espaço de reflexão por representar os conflitos humanos e torná-los próximos dos receptores e, na maioria das vezes, servindo como uma verdadeira prática de esclarecimento de condutas as quais nutrem a referência do telespectador.

Para Lopes (2014), o telespectador vive imerso numa verdadeira cultura da comunicação que está assentada na percepção que se tem sobre o outro bem como no reconhecimento do indivíduo como componente principal do agir comunicativo. Nas palavras da autora: "É dentro desse universo de sentidos que podemos conceber a institucionalização singular da telenovela brasileira na cultura e na sociedade como um recurso ou uma "alavanca" que pode ser ativada na persecução da cidadania cultural [...]" (LOPES, 2014, p.07). Nesse sentido, as telenovelas, enquanto componente

máximo da sociedade audiovisual, atuam como elemento de socialização e fonte pedagógica, sobretudo, por esclarecer condutas, legar valores e informações, comportando-se como grande fator de emancipação.

\section{Telenovela e Identidade Nacional}

A questão acerca das identidades é extremamente importante na contemporaneidade. Esse conceito amplamente discutido ganhou contornos relevantes devido ao estágio de globalização experimentado, o que alimentou ainda mais esse debate. Primeiramente, é necessário afirmar que o conceito de identidade, nas palavras de Bauman (2005), não passava de uma convenção que foi apreendida e assimilada ao longo do tempo. Basta se lembrar que de início, tal conceito era ditado pelo nascimento do indivíduo numa sociedade marcada pela estratificação. Mais tardiamente, o conceito passou a se relacionar com o papel que o indivíduo ocupava na pirâmide de trabalho.

Ao explicar a identidade, Bauman se posiciona da seguinte forma:

\begin{abstract}
Tornamo-nos conscientes de que o "pertencimento" e a "identidade" não têm solidez de uma rocha, não são garantidos para toda a vida, são bastante negociáveis e revogáveis, e de que as decisões que o próprio indivíduo toma, os caminhos que percorre, a maneira como age - e a determinação de se manter firme a tudo isso - são fatores cruciais tanto para o "pertencimento" quanto para a “identidade.” (BAUMAN, 2005, p. 17).
\end{abstract}

É lícito afirmar que Bauman encara as identidades como transitórias à medida em que se alteram em virtude das relações entre os seres se notabilizarem por serem cada vez mais fluidas. Por esse motivo, as estudiosas Figueiredo e Noronha (2015, p. 189) asseveram que “a questão das identidades na modernidade tardia é complexa, uma vez que se trata de ocupar contornos mais fluidos sem contornos definidos". Para Hall (2001, 
p.03), "a identidade é um assunto amplamente discutido na teoria social". O autor postula que é um conceito importante para se compreender as relações sociológicas de fim de século. Assim, o teórico postula que "as velhas identidades que por tanto tempo estabilizaram o mundo social estão em declínio, fazendo surgir novas identidades e fragmentando o indivíduo moderno, até aqui visto como um sujeito unificado" (HALL, 2001. p.07). Em suas teorizações, o autor sustenta que há identidades plurais, encarada como processo mais amplo de mudança e defende que as identidades estão sempre em formação, não sendo fixas, estáticas, mas sim alteráveis, podendo-se concluir que as identidades não são elaboradas isoladamente, mas negociadas pelo indivíduo durante toda a vida.

Em sua obra intitulada A identidade cultural na pós-Modernidade, o estudioso jamaicano Stuart Hall aponta para uma crise acerca da identidade e a delineia como um processo mais amplo de mudança. Dessa forma, o grande objetivo do autor é buscar explorar questões relacionadas com a identidade cultural na modernidade tardia bem como avaliar se há uma crise a respeito do tão discutido conceito. Nas palavras do autor, identidade trata-se de "um conceito demasiadamente complexo, pouco desenvolvido e muito pouco compreendido na ciência social contemporânea" (HALL, 2001, p.08).

Não se pode se esquecer de que a questão da identidade liga-se às heranças sociais e culturais. É um conceito que se forma pela vivência em grupos que mantêm hábitos parecidos. Tal conceito é amplamente discutido $\mathrm{Na}$ atual conjectura, porque na atualidade se tem um indivíduo multicultural. Dessa forma, pode-se falar que o conceito ora antes fixo, deve ser revigorado, porque o indivíduo contemporâneo busca identidades em movimento. Para Stuart Hall, as identidades estão em declínio, fazendo surgir novas identidades e fragmentando o indivíduo. "O sujeito, previamente vivido como tendo uma identidade unificada e estável, está se tornando fragmentado; composto não de uma única, mas de várias identidades" (HALL, 2001. p.12).

Utilizando postulações de Figueiredo e Noronha (2005), percebe-se que esse ser é caracterizado pelas identidades contraditórias, sendo constantemente deslocadas em função dos elementos nacionais, culturais, de gênero, de classe social, de posição política e religiosa. Enfim, são várias as identificações formadoras do mosaico do nosso eu. Dessa forma, a atual etapa da sociedade constituí-se como um período de profundas transformações sociais. É um período em que se presencia um forte desenvolvimento da imprensa e da comunicação. Trata-se de uma era marcada pela velocidade dos descobrimentos. Afinal, nunca se teve tantas descobertas em período de tempo pouco reduzido. Dessa forma, a sociedade vive em prol de novas buscas, tendo novos anseios porque a realidade na qual está inserido é outra bastante diferente de períodos anteriores.

A sociedade do consumo, a sociedade globalizada e a profunda dependência das mídias são um reflexo desses novos tempos, o que altera constantemente a identidade dos indivíduos. De modo geral, o homem do final do século XX não se apresenta com uma identidade única, mas com várias identidades, que são alteráveis e descartáveis. Para esse homem, há uma crise na crença e no conhecimento. Por essa razão, há uma incapacidade de se manter crente em suas convicções ao mesmo tempo em que acredita ser o conhecimento meramente transitório. Assim, a crise desse sujeito é evidenciada pelas suas atitudes cada vez mais superficiais, ensimesmadas e fluidas.

$\mathrm{O}$ advento do moderno, aliás, suscita uma série de nomenclaturas. Os próprios teóricos, como Stuart Hall, alternam a designação para se referir a esse tipo de sujeito como forma de acompanhar as mudanças. No geral, as expressões empregadas 
para se referir a essa era são: "pós-modernidade", "modernidade líquida", "modernidade tardia", "sobremodernidade" e "hipermodernidade". Outros, por sua vez, preferem designar apenas por modernidade por acreditarem que não ocorreram mudanças significativas como a que houve pelo intermédio dos ideais iluministas calcados na explicação racional da humanidade.

Relacionando-se as teorizações ora apresentadas com as narrativas teleficcionais, pode-se compreender que os estudos acerca do gênero telenovela são fundamentais para a compreensão da cultura contemporânea, bem como para a construção da identidade nacional. Mais que isso, "os produtos da mídia, portanto, não são entretenimento inocente, mas têm cunho perfeitamente ideológico e vinculam-se à retórica, a lutas, a programas e ações políticas" (KELLNER, 2001, p.123).

Embora os estudos acerca do gênero telenovela levaram cerca de três décadas para começar a refletir na influência desse gênero no campo cultural brasileiro, ele ganhou visibilidade, sobretudo, a partir de ideais oriundos da linha de Estudos Culturais.

Utilizando postulações de Motter:

\begin{abstract}
A telenovela pode ser considerada no contexto brasileiro, o nutriente de maior potência do imaginário nacional e, mais do que isso, ela participa ativamente na construção da realidade, num processo permanente em que ficção e realidade se nutrem uma da outra, ambas se modificam, dando origem a novas realidades, que alimentarão outras ficções, que produzirão novas realidades (MOT'TER, 2003, p.174).
\end{abstract}

A partir dessas postulações, pode-se se perceber, então, o quão importante se faz necessário estudas as mídias, sobretudo, as telenovelas, como forma deinterpretaro país bem comouma referência para balizar questões identitárias. Ademais, como ensina Tondato (2011), pensar a comunicação na América Latina é pensar na teleficção como uma forma consistente de referência para a construção de identidade (s):

A mídia, cuja força social é indiscutível na
contemporaneidade, como mais um sistema
simbólico a elaborar e representar as culturas,
tem seu papel reforçado na construção das
identidades, sejam as individuais ou as coletivas.
A relação com as identidades individuais se
estabelece no processo de representação que
faz transparecer o modo como as sociedades
se reconhecem e, portanto, são representadas
(TONDATO, 2011, p.293).

Silverstone (2002) afirma que o trabalho com mídias deve ser pautado como dimensão social, cultural, política e econômica do mundo moderno. "Estudá-la como dimensão social e cultural, mas também política econômica, do mundo moderno. Estudar sua onipresença e sua complexidade. Estudá-la como algo que contribui para nossa variável capacidade de compreender o mundo, de produzir seus significados" (SILVERSTONE, 2002, p. 13).

Pela profundidade dos temas retratados e pelo serviço de formativo que prestam à nação, é indiscutível que a telenovela deixou de ocupar o posto de mero entretenimento para se consolidar numa narrativa acerca da nação. "Alçada à posição de principal produto de uma indústria televisiva de grandes proporções, a novela passou a ser um dos mais importantes e amplos espaços de problematização do Brasil, indo da intimidade privada aos problemas sociais" (LOPES, 2009, p.06). Pode-se falar, então, de acordo com o ponto de vista da autora, que a telenovela tornou-se uma forma de narrativa sobre a nação e um modo de participar dessa nação imaginada.

\section{Considerações Finais}

O presente artigo tratou acerca da constituição da telenovela, enfocando suas relações com as matrizes populares até sua constituição 
como uma narrativa acerca do país fortemente constituída como um recurso comunicativo. Presente no país desde 1951, sua trajetória é inerente ao desenvolvimento da televisão. De início, essa narrativa teleficcional foi encarada com forte preconceito por ser considerada uma forma de entretenimento alienante devido ao forte componente melodramático que grassava em sua constituição.

Nos últimos 40 anos, o gênero ganhou reconhecimento acadêmico sendo alçado ao posto de um verdadeiro produto cultura brasileiro. Assim, esse "folhetim eletrônico repaginado" promove amplamente o processo de identificação dos telespectadores com os personagens num processo em que o real e o ficcional se misturam. Pode-se falar também que a narrativa teleficcional promove um amplo debate na sociedade por dar visibilidade a temáticas complexas e polêmicas, constituindo-se num verdadeiro fórum de debates na nação.

Longe de esgotar as postulações acerca da telenovela, este artigo concentra seu foco em creditar à telenovela, enquanto produto de ficção seriada, a capacidade de se constituir uma narrativa acerca do país. Esse gênero foi conquistando seu espaço enquanto objeto privilegiado de promoção de identidade nacional, ganhando visibilidade em torno da cultural nacional, tornando-se indispensável para a compreensão da cultura contemporânea. Ademais, alçada à principal produto de uma indústria televisiva, a telenovela passou a ser um dos mais importantes e amplos espaços de problematização e representação do país.

\section{Referências}

AIRES, ALIANA Barbosa. A teleficção brasileira ensinando a consumir. Anais do $4^{\circ}$ Congresso Internacional de Comunicação. São Paulo, ESPM, 2014.
ALENCAR, Mauro. A Hollywood Brasileira: Panorama da Telenovela no Brasil, São Paulo: Senac, 2002.

ARNT. Héris. Jornalismo e ficção: as narrativas do cotidiano. Revista Contemporânea. Edição n ${ }^{\circ} 03$ Ano I - Jul/Dez 2004.

BAUMAN, Zygmunt. Identidade. Rio de Janeiro: Jorge Zahar Editor, 2005.

COSTA, Cristiane. Eu compro essa Mulher: romance e consumo nas telenovelas brasileiras e mexicanas. Rio de Janeiro: Jorge Zahar, 2000.

FIGUEIREDO, Eurídice. NORONHA, Jovita Maria G. Identidade Nacional e Identidade Cultural. In: FIGUEIREDO, Eurídice (org.). Conceitos de Literatura e Cultura. Juiz de Fora: UFJF, 2005.

HALL, Stuart. A identidade cultural na pósmodernidade. 6. ed. Rio de Janeiro: DP\&A. Editora, 2001.

HAMBURGER, Esther. O Brasil antenado: A sociedade da telenovela. Rio de Janeiro: Jorge Zahar, 2005

KELLNER, Douglas. A cultura da mídia. Bauru: Edusc, 2001.

LOPES, Maria Immacolata Vassallo de ; MUNGIOLI, Maria Cristina Palma . Qualidade da Ficção Televisiva no Brasil: elementos teóricos para a construção de um modelo de análise. In: XXII Encontro Anual da Compós, 2013, Salvador. Campós 2013 - Anais, 2013.

LOPES, Maria Immacolata Vassallo de. Telenovela como Recurso Comunicativo. MATRIZES, v. 3, n.1, 2009.

LOPES, Maria ImmacolataVassallo de. Memória e Identidade na Telenovela Brasileira. Disponível em < http://compos.org.br/encontro2014/anais/ Docs/GT12 ESTUDOS DE TELEVISAO/ templatexxiiicompos 2278-1 2246.pdf $>$. Acesso em 04/05/2016.

MEYER, Marlyse. Folhetim: uma história. São 
Paulo: Companhia das Letras, 2005.

MOTTER, Maria. Telenovela Internacionalização e Interculturalidade. Edições Loyola, São Paulo, 2003.

PALLOTTINI, Renata. Dramaturgia de televisão. 2. ed. São Paulo: Boitempo, 2012.

POSTIGO, Vanderlei. A questão da autoria em telenovelas brasileiras. Anuário da Produção Acadêmica Docente Vol. XII, Nº. 2, Ano 2008.

SADEK, José Roberto. Telenovela: Um olhar do cinema, São Paulo: Summus, 2008.

SILVERSTONE, Roger. Por que Estudar a Mídia?São Paulo: Edições Loyola, 2002.

TÁVOLA, Artur da. A telenovela brasileira: história análise e conteúdo. São Paulo: Globo, 1996.

TONDATO, Marcia Perencin. Comunicação e consumo: representações identitárias da mulher na publicidade do prime-time. Revista ECO-POS, abril, 2011.

Recebido em 17 de junho de 2017

Aceito em: 30 de setembro de 2017 